\title{
УДК 378.174:004.588
}

\section{Олексюк Олеся Романівна}

аспірант

Інститут інформаційних технологій і засобів навчання НАПН України, м. Київ, Україна oolessia@gmail.com

\section{Олексюк Василь Петрович}

кандидат педагогічних наук, доцент, доцент кафедри інформатики та методики їі викладання Тернопільський національний педагогічний університет імені Володимира Гнатюка, м. Тернопіль, Україна

oleksyuk@fizmat.tnpu.edu.ua

\section{ІНТЕГРАЦІЯ ІНСТИТУЦЙНОГО РЕПОЗИТАРІЮ В ІНФОРМАЦІЙНО-ОСВІТНЕ СЕРЕДОВИЩЕ ВНЗ}

\begin{abstract}
Анотація. У статті проаналізовано поняття, пов'язані з процесами інтеграції програмних засобів навчального призначення. Запропоновано шляхи інтеграції інституційного репозитарію, організованого на основі системи DSpace, 3 популярними системами навчального призначення (LMS MOODLE, CMS Joomla!, УФД бібліотека) і системами підтримки наукових досліджень (на основі Microsoft Sharepoint). Інтеграція зазначених засобів можлива на рівні контенту й уніфікації доступу. Реалізація інтеграційних зв'язків забезпечує ефективне використання системи DSpace у науково-дослідній роботі й навчальній діяльності майбутніх учителів інформатики.

Ключові слова: інституційний репозитарій; інтеграція інформаційних систем; Enterprise Application Integration інформаційно-освітнє середовище; DSpace; LMS MOODLE; CMS Joomla!; Microsoft Sharepoint; Microsoft Office365; УФД бібліотека.
\end{abstract}

\section{1. ВСТУП}

Однією із сучасних тенденцій упровадження інформаційно-комунікаційних технологій в освітню галузь $є$ застосування різноманітних програмних засобів навчального призначення. Наразі постає проблема їх інтеграції, зокрема 3 метою формування єдиного інформаційного середовища освітнього закладу.

3 технологічної точки зору зазначене середовище $\epsilon$ сукупністю технічних $\mathrm{i}$ програмних засобів зберігання, систематизації та поширення наукової інформації. Основним завданням функціонування науково-інформаційного середовища $\epsilon$ забезпечення вільного доступу до інформаційних ресурсів, створення умов для наукової комунікації.

Постановка проблеми. Оскільки ефективність навчальної діяльності і науководослідної роботи безпосередньо залежить від ії ресурсного забезпечення, то програмні засоби інформаційно-освітнього середовища мають надавати доступ до матеріалів, які опубліковані у його межах. Для цього доцільно максимально інтегрувати програмні засоби у межах навчально-інформаційного середовища.

Аналіз останніх досліджень і публікацій. Проблема створення й ефективного використання інституційних репозитаріїв активно досліджується науковцями. Проблеми інформатизації системи освіти розглядалися у працях М. І. Жалдака, Ю. А. Жука, В. Ю. Бикова, Н. В. Морзе, Ю.С. Рамського та ін. Теоретичні аспекти проектування системи електронних бібліотек наукових i навчальних закладів присвячені дослідження О. Б. Антопольского, О. М. Спіріна, С. М. Іванової. Аналізу функціональних можливостей деяких систем електронних бібліотек присвячені роботи дослідників В. А. Резніченка, Г. Ю. Проскудіної, К. О. Кудима, О. В. Новицького та ін. 
Проблеми популяризації ініціатив відкритого доступу відображені у працях О. М. Бруй, С. А. Назаровця, Т. О. Ярошенко, В. О. Копанєвої. У роботах А. І. Андрухіва, О. Г. Кузьміна, Д. О. Тарасова розкрито деякі аспекти запровадження архівів відкритого доступу в роботу університетських бібліотек. Дослідження Н. Т. Задорожної, Т. В. Кузнецової, А. В. Кільченко, Х. В. Середи, С. М. Тукала, О. О. Каплун, Л. А. Лупаренко та інших присвячені проблематиці методології наукової й управлінської діяльності, зокрема за умови функціонування електронної бібліотеки навчального закладу чи наукової установи. У багатьох наукових дослідженнях звертають увагу на інтеграційну функцію інституційного репозитарію як важливого засобу інтеграції наукових публікацій вітчизняних науковців до світового інформаційного наукового простору. Не розкритою є проблема вивчення шляхів інтеграції інституційного репозитарію 3 існуючими системами навчального призначення.

Мета статті полягає в уточненні понять «інформаційно-освітнє середовище», «інтеграція програмних засобів»; у визначенні напрямів інтеграції інституційного репозитарію, побудованого на основі системи DSpace 3 популярними системами навчального призначення (LMS MOODLE, CMS Joomla!, УФД бібліотека, системи документообігу) як на рівні контенту, так і через уніфікацію доступу користувачів.

\section{2. МЕТОДИ ДОСЛІДЖЕННЯ}

Під час дослідження використовувались методи аналізу науково-методичної літератури 3 проблематики впровадження інституційних репозитаріїв, науковотехнічної літератури з проблеми й інтеграції програмного забезпечення, моделювання і проектування інтегрованих складових інформаційно-освітнього середовища.

\section{3. РЕЗУЛЬТАТИ ДОСЛІДЖЕННЯ}

\section{1. Аналіз основних понять дослідження}

У галузь освіти епоха інформатизації принесла значну кількість програмних засобів навчального призначення, які у своїй сукупності можуть утворювати навчальні середовища й освітні простори. Як зазначають С. А. Башенков, Е. А. Ракітіна, В. Ю. Лискова, поняття «простір» і «середовище»є близькими, але не синонімічними. Аналізуючи співвідношення цих понять, дослідники мають на увазі набір певним чином пов'язаних між собою умов, які можуть впливати на людину. Наразі у понятті «простір» не передбачено присутність у ньому людини. Простір може існувати i незалежно від неї, а середовище передбачає взаємодію і взаємовплив оточення із суб'єктом [2]. На думку Ю. О. Жука, інформаційне середовище можна визначити як ту частину інформаційного простору, яка формує найближче інформаційне оточення індивіда, виступає як сукупність умов, що певною мірою забезпечують його продуктивну діяльність. Мета цієї діяльності визначає те інформаційне середовище, яке обирає людина [10].

У дослідженні [20] запропоновано поняття інформаційно-предметного середовища, що в сукупності з елементами технології навчання містить засоби i технології збирання, накопичення, передавання, опрацювання та розповсюдження навчальних матеріалів і реалізує зв'язки між ними і їх функціонування.

Врахувавши запропоноване у [5] трактування навчального середовища, можемо стверджувати, що навчально-інформаційне середовище $є$ інформаційною системою, 
структура і складові якої створюють необхідні умови для досягнення цілей навчальновиховного процесу. Інформаційно-освітне середовище розуміють як сукупність технічного, інформаційного та навчально-методичного забезпечення, яка нерозривно пов'язана з людиною як суб'єктом навчання [9; 19]. Згадана інформаційна система, як правило, не $\epsilon$ однорідною, а містить різні програмні засоби навчального призначення. Як наслідок постає проблема їх інтеграції.

У філософському трактуванні інтеграція визначається як процес, що пов'язаний 3 об'єднанням у ціле раніш різнорідних частин й елементів. Процеси інтеграції можуть мати місце як у межах існуючої системи - у цьому випадку вони ведуть до підвищення рівня іiі цілісності й організованості, так і під час створення нової системи 3 раніш не пов'язаних елементів [26, с. 474].

Інтеграція програмних засобів організації полягає у застосуванні структурного підходу EAI (Enterprise Application Integration) до програмного забезпечення або інформаційних систем організації з метою їх об'єднання згідно певних критеріїв. Такими критеріями можуть бути інтеграція даних додатків, забезпечення спільної автентифікації їх користувачів, незалежність від одного розробників, уніфікований інтерфейс [28].

Об'єднання ресурсів не обов'язково має здійснюватися фізично, воно може бути віртуальним, проте воно має забезпечувати користувачеві сприйняття доступної інформації як єдиного інформаційного середовища. Зокрема передбачається, що електронні бібліотеки мають забезпечувати роботу з гетерогенними базами даних, забезпечуючи користувачеві ефективність інформаційних пошуків незалежно від особливостей конкретних інформаційних систем [28].

Якщо інтеграцію здійснюють без урахування підходу EAI, то можливе попарне об'єднання програмних засобів. У міру збільшення кількості інтегрованих додатків зростає складність самої інформаційної системи і як наслідок збільшуються витрати на iї підтримку. Наприклад, двоточкове об'єднання $n=10$ додатків передбачає створення $\frac{n(n-1)}{2}=45$ зв' язків.

Існують дві моделі, які реалізують підхід ЕАІ.

1. Інтракомунікація, згідно якої ЕAI $\epsilon$ посередником між окремими програмними засобами. У разі виникнення події у додатку відбувається іiі опрацювання у модулі інтеграції.

2. Інтеркомунікація - усі взаємодії інформаційної системи із «зовнішнім світом» відбуваються через EAI, яка надає доступ до окремих даних й інтерфейсів i забезпечує усі взаємодії з внутрішніми додатками.

У контексті дослідження під інтеграцією розумітимемо етап створення інформаційно-освітнього середовища, який полягає в об'єднанні програмних засобів навчального призначення 3 метою отримання нових i підвищення існуючих функціональних можливостей.

Серед складових загально інтеграційного процесу розвитку освіти В. Ю. Биков виділяє процеси інтеграції навчально-методичного забезпечення (у тому числі електронних інформаційних ресурсів), організаційно-функціональної і структурної будови системи освіти, методів, засобів і технологій наукової діяльності, комп'ютерних мереж навчальних закладів, наукових установ i органів управління освітою, баз освітніх і наукових даних і бібліотечної справи (у тому числі забезпечення захисту i рівного доступу до ресурсів цих баз, інтеграція баз даних в єдиному інформаційному освітньому просторі) [3]. Зокрема, засоби і технології корпоративної ІКТ-системи мають утворювати в освітній організаційній структурі (OOC) гнучке й адаптивне інтегроване організаційно-технологічне й інформаційно-обчислювальне середовище, 
що розвивається й активно і визначально впливає на формування в ООС найбільш сприятливих (інформаційно-комфортних) умов для ефективного здійснення ії функцій [4].

Як зазначають автори колективної монографії [12, с. 65-66] процес інформатизації, серед іншого, полягає у побудові й упровадженні інформаційної вебсистеми не у вигляді окремого об'єкта глобальної мережі, а як складника корпоративного середовища, у якому діє сукупність веб-систем, що обмінюються окремими даними або потоками даних.

\section{2. Шляхи інтеграції інституційного репозитарію}

Інтеграція між програмними засобами здійснюється, в основному, на рівні контенту (навчального матеріалу). Для здійснення такої інтеграції засоби повинні підтримувати стандарти, що регламентують вимоги до контенту й основних операцій щодо його використання [15].

Аналізуючи структуру інформаційно-освітніх середовищ ВНЗ України $[17 ; 21 ; 14$; 15], можна зробити висновок про широке застосування у них вільного програмного забезпечення. Попри це, обираючи той чи інший програмний засіб навчального призначення, фахівці зупиняються на найбільш функціональних і підтримуваних зразках. Це означає, що їх інтеграція згідно підходу ЕАІ буде вимагати значних зусиль.

Розглядаючи інтеграцію системи DSpace у науково-інформаційне середовище ВНЗ, можна виділити такі аспекти:

- єдина автентифікація користувачів інституційного репозитарію та інших сервісів середовища ВН3;

- можливість отримувати доступ до матеріалів інституційного репозитарію у межах усього науково-інформаційного середовища.

Як показує досвід, доступ до ресурсів значної кількості програмних засобів навчального призначення $є$ персоніфікованим. Тобто для роботи з певним програмним засобом користувачеві необхідно підтвердити свою достовірність або, як кажуть, пройти автентифікацію. Оскільки програмних засобів у складі навчальноінформаційного середовища може бути чимало, то постає проблема уніфікування зазначеного процесу, яку можна забезпечити впровадивши так звану єдину систему автентифікації.

У [17] зазначено, що така система може бути організована відповідно до однієї 3 концепцій:

- синхронізація даних з обліковими записами користувачів усіх програмних засобів;

- використання спільної бази даних облікових записів користувачів, проте для доступу до кожного засобу необхідна окрема автентифікація;

- механізм, за допомогою якого єдина дія щодо автентифікації й авторизації користувача надає йому доступ до всіх складових навчальноінформаційного середовища.

Для того щоб зупинитися на одній з перелічених концепцій, слід проаналізувати можливості системи DSpace щодо автентифікації користувачів репозитарію. Офіційна документація системи описує модулі, які здійснюють автентифікацію на основі [27]:

- внутрішньої бази даних репозитарію;

- IP-адреси комп'ютера користувача;

- сертифікату Х.509 користувача;

- каталогу і відповідного протоколу LDAP (Lightweight Directory Access Protocol); 
- технології єдиного входу (SSO - single sign-on), реалізованій у програмному пакеті Shibboleth.

Оскільки у багатьох освітніх закладах використовується доменна структура організації мережі, то технічно простішим й організаційно виправданим $є$ використання каталогу LDAP як бази облікових записів. Такий каталог $є$ основою функціонування поширених доменних платформ (Microsoft Active Directory, OpenLDAP). Проте реалізована система єдиної автентифікації вимагатиме окремого введення реєстраційних даних для доступу до кожного програмного засобу, зокрема й до системи DSpace. На рис. 1 зображено процес автентифікації користувачів інституційного репозитарію, облікові записи яких зберігаються у каталозі LDAP.

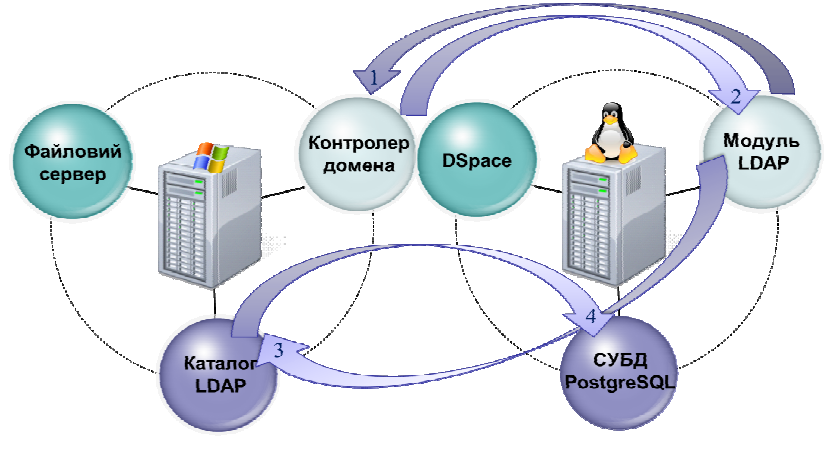

Pис. 1. Автентифікація користувачів системи DSрасе на основі LDAP-каталогу

Коротко зупинимося на її основних етапах (зображені у вигляді пронумерованих стрілок).

1. Модуль для роботи з каталогом LDAP авторизується у системі контролера домену.

2. Модуль отримує дозвіл для читання каталогу LDAP.

3. Модуль виконує пошук облікового запису користувача у каталозі LDAP i перевіряє його достовірність.

У випадку, якщо користувач авторизується вперше, здійснюється збереження його облікового запису у базі даних системи DSpace.

У конфігурації згаданого модуля слід вказати відповідність полів каталогу LDAP i системи DSpace, зокрема обов'язкових: ім'я, прізвище, електронна адреса користувача. Додатково корисним може бути визначення окремої групи у системі DSpace, до якої буде долучено усіх користувачів, яких авторизовано за допомогою протоколу LDAP. Зазначена група спростить адміністрування інституційного репозитарію, особливо у випадку, якщо він використовується у навчальних цілях, а, отже, матеріали студентів не проходять окреме затвердження редактором.

Каталог LDAP може бути основою єдиної системи автентифікації, з якою, крім «традиційних» засобів навчального призначення, можуть функціонувати й хмарні платформи. Наприклад, у публікаціях [16; 18] описано досвід інтеграції засобів публічних хмар Google Apps i Microsoft Office365 в інформаційно-освітнє середовище BH3.

Існує можливість забезпечення доступу до всіх сервісів внаслідок єдиної дії щодо автентифікації й авторизації користувача. Зокрема, можна використати програмний продукт Shibboleth. Такий шлях вимагає конфігурування окремого провайдера автентифікації.

Описаний підхід реалізує парадигму єдиного облікового запису, за допомогою якого студент отримує доступ до усіх сервісів навчально-інформаційного середовища ВНЗ не лише під час навчання в університеті, а й у подальшій професійній діяльності. 
Оскільки інституційний репозитарій $є$ складовою навчально-інформаційного середовища ВНЗ, то доцільно забезпечити можливість використання його матеріалів у інших програмних засобах навчального призначення. Таке завдання може бути розв'язане як реалізованими засобами системи DSpace, так і через розробку окремих програмних модулів. На рис. 2 виокремлено такі реалізовані нами можливості системи DSpace, які доцільно використовувати для іiі інтеграції.

Найпростішим засобом отримання матеріалів 3 репозитарію на веб-сторінках $€$ технологія синдикації даних RSS (Really Simple Syndication). Система DSpace має вбудовані засоби щодо формування послідовності матеріалів у форматі RSS.

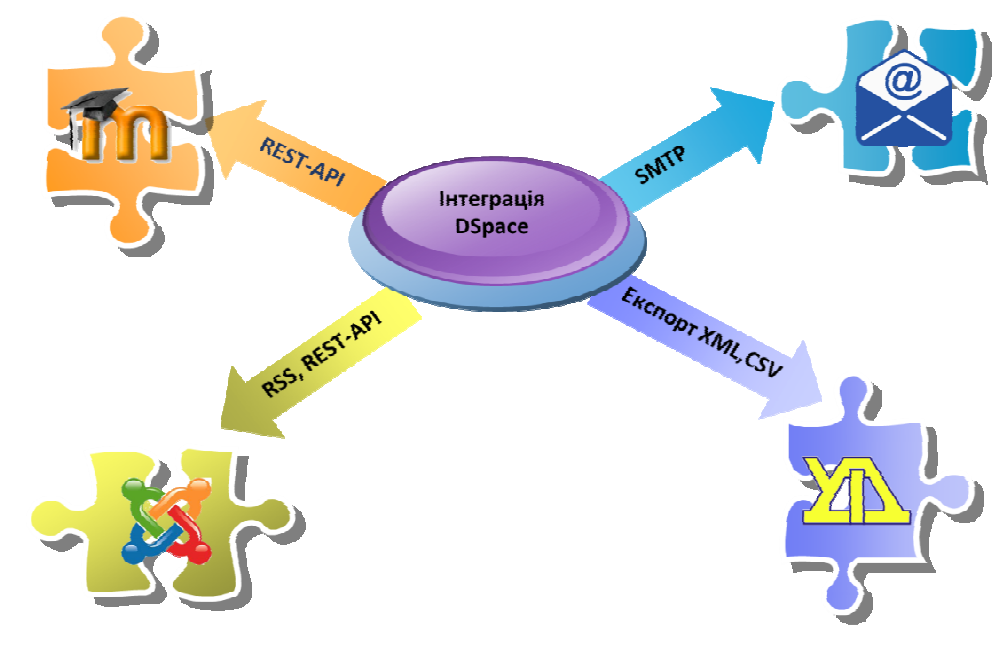

Рис. 2. Можливості інтеграції системи DSрасе для обміну матеріалами

Наприклад, у такий спосіб нами було додано модуль «Нові матеріали у ФМрепозитарії» на веб-портал, який працює на основі CMS Joomla! Зазначений модуль виконує виведення посилання на останні надходження у репозитарій (рис. 3).

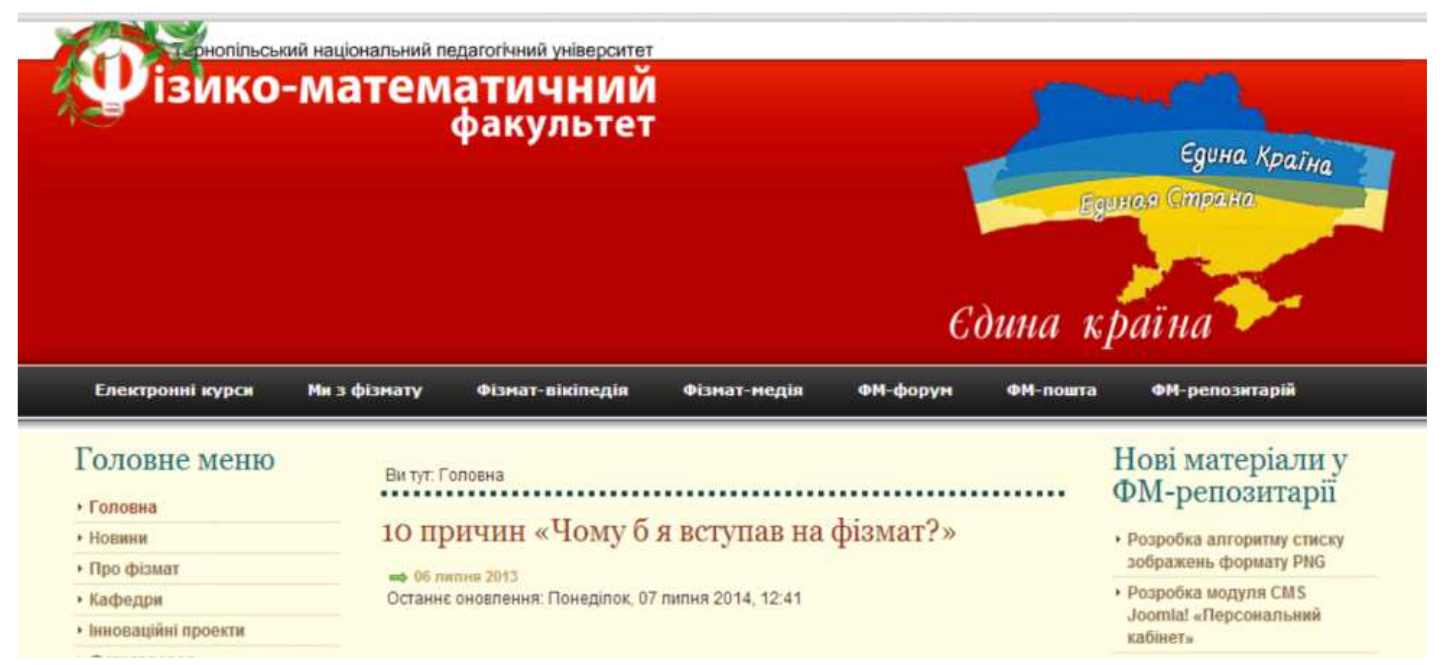

Рис. 3. Модуль для синдикації даних з інституційного репозитарію

Ще однією реалізованою функцією платформи DSpace $\epsilon$ можливість надсилання повідомлень за протоколом SMTP. Отож, користувачі репозитарію можуть підписатися й отримувати повідомлення про надходження матеріалів у репозитарій або певну його колекцію. 
Важливим аспектом застосування інституційного репозитарію у навчальноінформаційному середовищі є їі інтеграція із системами управління навчанням. Значна кількість вітчизняних досліджень демонструють неабияку популярність LMS MOODLE в Україні.

3 метою надання доступу до матеріалів, які опубліковані у системі DSpace, iii розробники створили API-інтерфейс [30]. Як наслідок у LMS MOODLE можна додавати модуль Dspace-repository, який забезпечує можливість пошуку і подальшого додавання матеріалів у електронні курси (рис. 4).

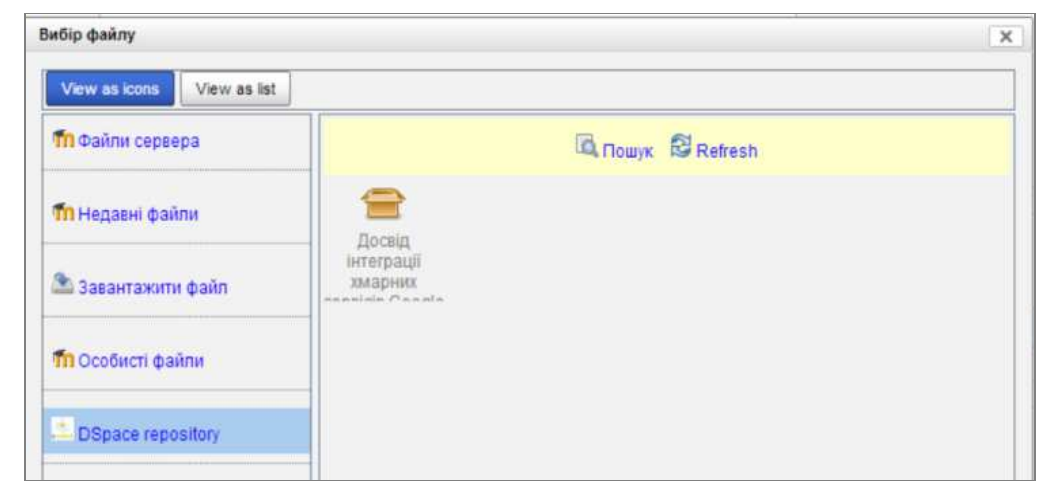

Puс. 4. Додавання матеріалів репозитарію у курс MOODLE

Розробляючи власні модулі для отримання даних із депозитарію, слід звернутися до інтерфейсу API-функцій як власне системи DSpace, так й інших програмних засобів навчального призначення. Зокрема, під нашим керівництвом було виконано розробку модуля «Персональний кабінет студента» системи управління контентом Joomla! [6]. Модуль реалізовано як компонент Joomla!, який серед іншого формує список опублікованих студентом матеріалів у системі DSpace, а також дозволяє переглядати їх (рис. 5).

\begin{tabular}{l}
\hline Головне Меню \\
, Головна \\
. Новини \\
, Про фізмат
\end{tabular}

Рис. 5. Перелік матеріалів, доданих автором у репозитарій

Стосовно інтеграції інституційного репозитарію 3 бібліотечними системи університету, то доцільним вважаємо здійснення експорту й імпорту метаданих з нього в електронні бібліотечні каталоги. Реалізація такої можливості може значно скоротити процес додавання матеріалів у інституційний репозитарій. У межах дослідження 
виконано експортування мета даних із системи «УФД бібліотека» 3 подальшим їх імпортуванням у електронний архів.

Як відомо, інституційний репозитарій є засобом підтримки не лише навчальнопізнавальної, а й науково-дослідницької діяльності [24; 8]. Для ії забезепечення часто використовують системи документообігу. Зокрема, в Інституті інформаційних технологій та засобів навчання НАПН України розроблено інформаційну систему «Наукові дослідження» [12].

До функціональних можливостей зазначеної системи належать:

- забезпечення документування науково-дослідної роботи працівниками НАПН України;

- формування, редагування, зберігання документів науково-дослідної роботи безпосередньо на Інтернет-порталі;

- автоматизація процесів документального супроводу науково-дослідної роботи:

- автоматичне створення папок і підпапок за визначеними правилами, у яких автоматично створюються документи відповідно до розроблених шаблонів;

- поширення значень однойменних полів у різних документах під час створення і їх подальша синхронізація у процесі формування документів;

- використання звичного для користувача програмного середовища Microsoft Office;

- використання єдиного сховища документів;

- забезпечення інформаційної безпеки і дотримання політики прав і дозволів на дії користувачів у системі 3 дотриманням належного рівня конфіденційності;

- відповідність структури, меню, сервісів дизайну Інтернет-порталу критеріям юзабіліті (англ. usability);

- забезпечення сервісу пошуку на порталі $[12 ; 21]$.

Головним інформаційним ресурсом такої системи є документ. Процес обробки документів у системі, який відповідає процесам діяльності науковців називається документообіг. Він передбачає передачу документів і розподілення задач між окремими виконавцями (науковцями, інженерами, керівництвом, бухгалтерами). У такому значенні говорять про робочий процес (workflow, потік робіт), який містить низку так званих бізнес-процесів. Їх у системі є два: «Запит» і «Виконання». Формальна модель управління документообігом складається 3 маршруту і шаблонів типових документів [11]. Систему «Наукові дослідження» побудовано на основі MS SharePoint системи управління вмістом сайту з інтегрованою функцією пошуку. Як показує досвід, розроблена система забезпечує виконання практично всіх завдань документообігу, щодо супроводу науково-дослідної роботи [13, с. 151].

Враховуючи, що розробка порталів НАПН України здійснювалася з урахуванням принципу інтероперабельності, то технічно можливою є їх взаємодія і функціонування 3 іншими продуктами або системами, зокрема і з електронними бібліотеками [13, с. 68]. Така інтеграція $\epsilon$ важливою 3 огляду на те, що кожен науковець завантажує опубліковані результати своєї наукової діяльності до репозитарію. Інтегрувавши відповідні модулі інформаційної системи «Наукові дослідження» і системи DSpace (Eprints), можна забезпечити автоматизацію формування переліку опублікованих матеріалів (монографій, статей, тез).

Як було зазначено вище, засобом для отримання матеріалів 3 репозитарію $\epsilon$ технологія RSS. Ї̈і підтримують практично всі платформи для розробки веб-додатків, зокрема i Microsoft SharePoint у «традиційній» і хмарній реалізаціях. 
Більш функціональним засобом інтеграції розглянутих систем є використання протоколу обміну метаданими (OAI-PHM - Open Archives Initiative Protocol for Metadata Harvesting). Враховуючи його функціональні можливості, технологічно доцільною вважаємо реалізацію як складової інформаційної системи «Наукові дослідження» модуля для збирання (harvesting) метаданих, опублікованих матеріалів інституційного репозитарію. Такими метаданими $є$ не лише традиційні бібліографічні дані, а й ідентифікатор URI (Uniform Resource Identifier), який є унікальним вказівником опубліковано матеріалу. Крім традиційного URI, існують ідентифікатори, які протокол використовує для виконання запитів, а також для отримання результатів. Дані, які передаються за протоколом OAI-PHM, є потоком байт, у загальноприйнятому форматі XML [31]. У мережі Інтернет присутні реалізації подібних модулів, зокрема, і для платформи SharePoint [29]. Крім цього реалізація зазначеного модуля можлива i засобами описаних вище REST-API функцій.

\section{4. ВИСНОВКИ ТА ПЕРСПЕКТИВИ ПОДАЛЬШИХ ДОСЛІЖЕНЬ}

Проблематика інтеграції інституційних репозитаріїв із програмними засобами навчального призначення в межах інформаційно-освітнього середовища $є$ актуальною $\mathrm{i}$ потребує подальшого дослідження. Інтеграція інституційного репозитарію можлива шляхом упровадження єдиної системи автентифікації його користувачів. Не менш важливим завданням $є$ забезпечення використання матеріалів електронної бібліотеки програмними засобами, які є складовими інформаційно-освітнього середовища. Обидва з описаних підходів реалізовані у межах дослідження, зокрема, як наслідок розгортання інституційного репозитарію фізико-математичного факультету Тернопільського національного педагогічного університету імені Володимира Гнатюка.

Зазначене середовище доцільно впроваджувати для підтримки навчальнопізнавальної і науково-дослідницької діяльності майбутніх фахівців, першочергово учителів інформатики. Наповнюючи репозитарій протягом навчання власними матеріалами, студент формуватиме у «персональному кабінеті» власне портфоліо, яке репрезентуватиме його як педагога, науковця, програміста, фахівця в галузі інформаційних технологій.

Не менш важливими $є$ завдання інтеграції інституційних репозитаріїв до інформаційних систем планування i супроводу наукових досліджень. Зокрема перспективним вважаємо розробку засобів для інтеграції систем DSpace i- Eprints 3 інформаційною системою «Наукові дослідження», яку впроваджено у Національній академії педагогічних наук України.

\section{СПИСОК ВИКОРИСТАНИХ ДЖЕРЕЛ}

1. Антопольский А. Б. Концепция электронных библиотек [Электронный ресурс] / А. Б. Антопольский, К. В. Вигурский // Электронные библиотеки. -1999. - Т. 2. - Вып. 2. Режим доступа : http://rd.feb-web.ru/vigursky-99.html.

2. Башенков С. А. Информация и информационные процессы / С. А. Башенков, В. Ю. Лыскова, Е. А. Ракитина // Информатика и образование. - 1998. — №8. - С. 39-51.

3. Биков В. Ю. Ключові чинники та сучасні інструменти розвитку системи освіти [Електронний ресурс] / В. Ю. Биков // Інформаційні технології і засоби навчання. - 2007. — №1. (2). — Режим доступу : http://journal.iitta.gov.ua/index.php/itlt/article/view/270/256\#.U8Emy5R_uSo.

4. Биков В. Ю. ІКТ-аутсорсінг і нові функції ІКТ-підрозділів навчальних закладів і наукових установ / В. Ю. Биков // Інформаційні технології і засоби навчання. — 2012. — № 4 (30). — С. 135-152. — Режим доступу : http://journal.iitta.gov.ua/index.php/itlt/article/view/717/529.

5. Биков В. Ю. Теоретико-методологічні засади моделювання навчального середовища сучасних педагогічних систем / В. Ю. Биков, Ю. О. Жук //Зб. наук. пр. - Вип. — 2003. — Т. 1. — №. 5. 
6. Ващак В. А. Розробка модуля CMS Joomla! «Персональний кабінет» [Електронний ресурс] / В. А. Ващак. — Режим доступу : http://elar.fizmat.tnpu.edu.ua/handle/123456789/858.

7. Воронцов А. Интеграция обучающих систем [Электронный ресурс] / Александр Воронцов. Режим доступа : http://wiki.itorum.ru/2011/02/integraciya-obuchayushhix-sistem/.

8. Іванова С. М. Проектування інформаційно-комунікаційної підтримки наукової діяльності на базі системи Eprints /Іванова СМ // Інформаційні технології і засоби навчання : електронне наукове фахове видання [Електронний ресурс]. - 2013. - С. 166-175. — Режим доступу : http://lib.iitta.gov.ua/1195/Іванова.№5_2013.pdf.

9. Ильченко О. А. Организационно-педагогические условия разработки и применения сетевых курсов в учебном процессе (на примере подготовки специалистов с высшим образованием ): автореф. дис. канд. пед. наук. / О. А. Ильченко. - М., 2002. - 20 с.

10. Жук Ю. О. Теоретико-методологічні проблеми формування інформаційного освітнього простору України [Електронний ресурс] / Ю. О. Жук // Інформаційні технології і засоби навчання; Інститут інформаційних технологій і засобів навчання АПН України. — 2007. — №2. - Режим доступу : http://www.ime.edu-ua.net/em3/content/07zuoeei.htm.

11. Задорожна Н. Т. Концепція створення інформаційної системи планування наукових досліджень АПН України на базі мережі Інтернет / Н. Т. Задорожна //Інформаційні технології і засоби навчання. - 2009. - №. 2. - С. 10.

12. Кільченко А. В. Вимоги до автоматизації обробки планово-фінансових документів в інформаційній системі планування наукових досліджень в Академії педагогічних наук України. / А. В. Кільченко Л.В.Лебеденко [Електронний ресурс] / А. В. Кільченко, Л. В. Лебеденко // Інформаційні технології і засоби навчання. - 2010. — №2 (16). — Режим доступу : http://journal.iitta.gov.ua/index.php/itlt/article/view/231/217\#.U7MOSbFnvvw.

13. Методологія інформатизації наукової та управлінської діяльності установ НАПН України на основі веб-технологій : монографія / [ Н. Т. Задорожна, Т. В. Кузнецова, А. В. Кільченко, Х. В. та ін.]. - К. : Атіка, 2014. - 160 с.

14. Морзе Н. В. Підготовка конкурентноздатного випускника магістратури в умовах сучасного університету / Н. В. Морзе, О. Г. Кузьмінська // Науковий часопис Національного педагогічного університету імені М. П. Драгоманова. Серія 5, Педагогічні науки: реалії та перспективи : наукове видання. - К. : Вид-во НПУ ім. М. П. Драгоманова, 2011. - Вип. 27. - С. 190-196.

15. Олексюк В. П. Деякі аспекти інтеграції веб-сервісів вищого навчального закладу / В. Олексюк, В. Габрусєв, А. Балик // Наукові записки Тернопільського національного педагогічного університету ім. В. Гнатюка. Сер. Педагогіка / гол. ред. Г. Терещук. — Тернопіль, 2011. — № 1. C. 228-234.

16. Олексюк В. П. Досвід інтеграції хмарних сервісів Google Apps у інформаційно-освітній простір вищого навчального закладу. [Електронний ресурс] / В. П. Олексюк // Інформаційні технології і засоби навчання. - 2013. - №3. http://journal.iitta.gov.ua/index.php/itlt/article/view/824/631.

17. Олексюк В. П. Єдина система автентифікації як крок до створення освітнього простору загальноосвітнього навчального закладу / В. П. Олексюк // Науковий часопис Національного педагогічного університету імені М. П. Драгоманова. Серія 2, Комп'ютерно-орієнтовані системи навчання . - К. : Вид-во НПУ ім. М. П. Драгоманова, 2012. - Вип. 13 (20). - С. 188-193

18. Олексюк В. П. Впровадження технологій хмарних обчислень як складових IT-інфраструктури ВНЗ. [Електронний ресурс] / В. П. Олексюк // Інформаційні технології і засоби навчання. — 2014. - №3. - $\quad$ Режим доступу до журналу http://journal.iitta.gov.ua/index.php/itlt/article/view/1042\#.U7KuwPkrbPA.

19. Рамський Ю. С. Активізація пізнавальної діяльності школярів засобами «ІнфоНІС» / С. О. Лещук, Ю. С. Рамський // Науковий часопис НПУ імені М.П. Драгоманова. Серія №2. Комп'ютерноорієнтовані системи навчання : зб. наукових праць / Редрада. — К. : НПУ імені М. П. Драгоманова, 2007. - №5 (12). - С. 120-125.

20. Роберт И. В. Теоретические основы создания и использования средств информатизации образования [Электронный ресурс] : автореф. дис. на соиск. учен. степ. д-ра пед. наук : спец. 13.00.02 / Ирэна Веньяминовна Роберт. — М., 1994. — 44 с — Режим доступа : http://www.childpsy.ru/dissertations/id/19536.php.

21. Середа Х. В. Вимоги до інформаційного забезпечення Інформаційної системи планування наукових досліджень в АПН України. Концептуальна модель даних [Електронний ресурс] / Х. В. Середа // Інформаційні технології і засоби навчання — 2010. — №2 (16) - Режим доступу: http://journal.iitta.gov.ua/index.php/itlt/article/view/232/218\#.U7MKGbFnvvw.

22. Співаковський О. В. Побудова ІКТ інфраструктури ВНЗ: проблеми та шляхи вирішення [Електронний ресурс] / О.В.Співаковський, М.О.Вінник, Ю. Г. Тарасіч // Інформаційні 
технології і засоби навчання. - 2014. - № 1 (39). — С. 99-116. — Режим доступу : http://journal.iitta.gov.ua/index.php/itlt/article/view/996\#.Uzz8sfl_t1Z.

23. Спірін О. М. Проектування системи електронних бібліотек наукових і навчальних закладів АПН України / [О. М. Спірін, В. М. Саух, В. А. Резніченко, О. В. Новицький] // Інформаційні технології і засоби навчання. — 2009 . - №6 (14). — Режим доступу: http://journal.iitta.gov.ua/index.php/itlt/article/view/213/199.

24. Спірін О. М. Концептуальні засади побудови мережі електронних бібліотек Національної академії педагогічних наук України / О. М. Спірін, С. М. Іванова, О. В. Новицький [Електронний ресурс] // Інформаційні технології і засоби навчання. - 2012. - №. 5. - Режим доступу : http://journal.iitta.gov.ua/index.php/itlt/article/view/743.

25. Створення освітнього web-простору для навчання [Електронний ресурс] / [В. М. Валуйський, М. В. Гончаренко, А. А. Павловський, А. О. Новацький]. - Режим доступу : http://uiite.kpi.ua/fileadmin/_wfqbe/1245139683_web.

26. Философский энциклопедический словарь / [гл. ред. Л. Ф. Ильичев]. - М. : Сов. энциклопедия, 1983. - $840 \mathrm{c}$.

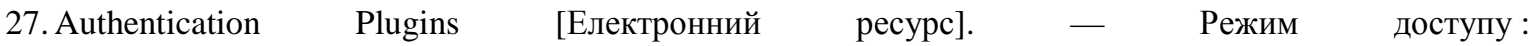
https://wiki.duraspace.org/display/DSDOC3x/Authentication+Plugins.

28. Keller W. Enterprise Application Integration / Wolfgang Keller. — Leseprobe, 2002. — 840 c.

29. OAI-PMH integrated search webpart [Електронний ресурс]. - Режим доступу : https://openarchiveswp.codeplex.com/.

30. REST API $\quad$ [Електронний ресурс]. - Pежим доступу : https://wiki.duraspace.org/display/DSPACE/REST+API.

31. The Open Archives Initiative Protocol for Metadata Harvesting [Електронний ресурс]. - Режим доступу : http://www.openarchives.org/OAI/openarchivesprotocol.html\#DefinitionsConcepts.

Матеріал надійшов до редакиї 28.10 .2014 p.

\title{
ИНТЕГРАЦИЯ ИНСТИТУЦИОННОГО РЕПОЗИТОРИЯ В ИНФОРМАЦИОННО-ОБРАЗОВАТЕЛЬНУЮ СРЕДУ ВУЗА
}

\author{
Олексюк Олеся Романовна \\ аспирант \\ Институт информационных технологий и средств обучения НАПН Украины, г. Киев, Украина \\ oolessia@gmail.com
}

\section{Олексюк Василий Петрович}

кандидат педагогических наук, доцент, доцент кафедры информатики и методики ее преподавания Тернопольский национальный педагогический университет имени Владимира Гнатюка,

Тернополь, Украина

oleksyuk@fizmat.tnpu.edu.ua

\begin{abstract}
Аннотация. В статье проанализированы понятия, связанные с процессами интеграции программных средств учебного назначения. Предложены пути интеграции институционного репозитория, организованного на основе системы Dspace, с популярными системами учебного назначения (LMS MOODLE, CMS Joomla!, УФД библиотека) и системами поддержки научных исследований (на основе Microsoft Sharepoint). Интеграция указанных средств возможна на уровне контента и унификации доступа пользователей. Реализация интеграционных связей обеспечивает эффективное использование системы Dspace в научно-исследовательской работе и учебной деятельности будущих учителей информатики.
\end{abstract}

Ключевые слова: институционный репозиторий; интеграция информационных систем; Enterprise Application Integration; информационно-образовательная среда; Dspace; LMS MOODLE; CMS Joomla!; Microsoft Sharepoint; Microsoft Office 365; УФД библиотека.

\section{INTEGRATION OF AN INSTITUTIONAL REPOSITORY ON INFORMATION AND EDUCATION ENVIRONMENT OF HIGHER EDUCATION INSTITUTION}




\title{
Olessia R. Oleksyuk
}

PhD student

Institute of Information Technologies and Learning Tools of NAPS of Ukraine, Kyiv, Ukraine. oolessia@gmail.com

\section{Vasyl P. Oleksyuk}

$\mathrm{PhD}$ (pedagogical sciences), Associate Professor of the Department of Informatics and methods of it's teaching Ternopil V. Hnatyuk National Pedagogical University, Ternopil, Ukraine.

oleksyuk@fizmat.tnpu.edu.ua

\begin{abstract}
The authors of article analyze the concepts associated with the processes of integration of software for the learning. The article contains ways of the integration institutional repository into educational environment of the universities. Authors are describing the experience of integration of DSpace system with the popular learning tools such as CMS Joomla!, LMS Moodle, UFD «Library». Integration of the specified tools is possible at the level of content and unification of access for users. The article contains opportunities of the integration DSpace and documents flow systems (based on Microsoft SharePoint). It is provided effective use of DSpace system at scientific and research work of students.
\end{abstract}

Keywords: information and education environment; institutional repository; enterprise application integration; DSpace; LMS MOODLE; CMS Joomla!

\section{REFERENCES (TRANSLATED AND TRANSLITERATED)}

1. Antopolsky A. Concept of digital libraries [online] / A. Antopolsky, KV Vigurskii // Digital Libraries. 1999. - V. 2, Vol. 2. — Available from : http://rd.feb-web.ru/vigursky-99.html (in Russian).

2. Bashenkov S. Information and Information Processes / S. Bashenkov, V. Lyskova, E. Rakitina. // Science and Education. — 1998. — №8. - P. 39-51 (in Russian).

3. Bykov V. Key factors and modern tools of education systems [electronic resource] / V. Bykov // Information technology and learning tools. [online ] / V. Bykov // Information Technologies and Learning Tools. $\quad-2008$. $\quad$ - 20 № $1(2) . \quad-\quad$ Available from : http://journal.iitta.gov.ua/index.php/itlt/article/view/270/256\#.U8Emy5R_uSo (in Ukrainian).

4. Bykov V. ICT-outsourcing and new functions of ict departments of educational and scientific institutions. [online] / V. Bykov // Information Technologies and Learning Tools. - 2012. — № 4(30). — P. 135152. — Available from: http://journal.iitta.gov.ua/index.php/itlt/article/view/717/529 (in Ukrainian)

5. Bykov V. Theoretical and methodological principles modeling learning environment of modern educational systems. [online] / V. Bykov O. Yu. Zhuk // Collection. Science. Pr., Vol._ 2003.— Vol 1.- №. 5 (in Ukrainian).

6. Vaschak V. Development module «Personal Account» for CMS Joomla! [online] / V. Vaschak. Available from: http://elar.fizmat.tnpu.edu.ua/handle/123456789/858 (in Ukrainian).

7. Vorontsov A. Integration training systems [online] / Alexander Vorontsov. - Available from : http://wiki.itorum.ru/2011/02/integraciya-obuchayushhix-sistem/ (in Russian).

8. Ivanova $S$. Design of information and communication support of scientific research on the Eprints basis /Ivanova S // Information Technologies and Learning Tools [online]. — 2013. — P. 166-175. — Available from : http://lib.iitta.gov.ua/1195/Іванова.№5_2013.pdf (in Ukrainian).

9. Ilchenko O. Organizational and teaching terms of application of Network courses in the training process. Abstract. Thesis of candidate dissertation of pedagogical sciences / O. Ilchenko. — M., 2002. — 20 p. (in Russian).

10. Zhuk Yu. Theoretical and methodological problems of formation of information education space Ukraine /Yu. Zhuk // Information Technologies and Learning Tools [online]. — 2007. — №2. — Available from : http://www.ime.edu-ua.net/em3/content/07zuoeei.htm (in Ukrainian).

11. Zadoroghna N. Conception of creation of the planning informative system of APS of Ukraine scientific researches on the Internet base/ N. Zadoroghna // Information Technologies and Learning Tools. 2009. - №2 (in Ukrainian).

12. Kilchenko A. Requirements for the automation of planning and financial documents in information systems planning research at the Academy of Pedagogical Sciences of Ukraine. / A. Kilchenko L. Lebedenko. - [online] // Information Technologies and Learning Tools. - 2010. - №2 (16). Available from: http://journal.iitta.gov.ua/index.php/itlt/article/view/231/217\#.U7MOSbFnvvw (in Ukrainian). 
13. The methodology of information science and management of institutions NAPS Ukraine-based technologies: monograph / Ed. col.: Zadorozhna N., T. Kuznetsova, A. Kilchenko, H. Wednesday, Tukalo S., A. Kaplun, L. Luparenko. — K. : Atika, 2014. — 160 p. (in Ukrainian).

14. Morze N. Prepare a competitive Masters graduate in modern university. / N. Morze, O Kuzminska // Scientific journal of NPU named after M. P. Drahomanov. Series 2. Computer-oriented educational systems: collection of scientific . - K. : NPU named after M. P. Drahomanov, №27. — P. 19-196 (in Ukrainian).

15. Oleksyuk V. Some aspects of the integration of web service of higher educational institutions. [online] / V. Oleksyuk, V. Gabrusev, A. Balyk// Scientific notes of Ternopil National Pedagogical University named after Volodymyr Hnatiuk. August. Pedagogy / editor. G. Tereshchuk. — Ternopil, 2011. — № 1.— P. 228-234. - Available from : http://dspace.tnpu.edu.ua/handle/123456789/98 (in Ukrainian).

16. Oleksyuk V. Experience of the integration cloud services google apps into information and educational space of higher educational institution. [online]/ V. Oleksyuk // Information technologies and learning tools. - 2013. — №3. - Available from : http://journal.iitta.gov.ua/index.php/itlt/article/view/824/631 (in Ukrainian).

17. Oleksyuk V. Unified authentication as a step towards the creation of the educational space of general educational institutions [online] / V. Oleksyuk // Scientific journal of NPU named after M. P. Drahomanov. Series 2. Computer-oriented educational systems: collection of scientific . - K. : NPU named after M. P. Drahomanov, 2012. - Issue №13 (20). - P. 188-193. — Available from : http://elar.fizmat.tnpu.edu.ua/handle/123456789/87 (in Ukrainian).

18. Oleksyuk V. Implementing cloud computing as a component of the it infrastructure university. [online]/ V. Oleksyuk // Information technologies and learning tools. — 2014. — №3. - Available from : http://journal.iitta.gov.ua/index.php/itlt/article/view/1042\#.U7KuwPkrbPA (in Ukrainian).

19. Ramskyj J. Activization of cognitive activity of school students means of "INFONIS". J. Ramskyj S. Leshchuk,. // Scientific journal of NPU named after M. P. Drahomanov. Series 2. Computer-oriented educational systems: collection of scientific. — K. : NPU named after M. P. Drahomanov. 2007. — Issue №5 (12). - P. 120-125 (in Ukrainian).

20. Robert I. Theoretical basis for the creation and use of informatization of education [online ] / I. Robert. Moskow : 1994. - Available from: http://www.childpsy.ru/dissertations/id/19536.php (in Russian).

21. Sereda H. Requirements for information support Information systems planning research in Pedagogical Sciences of Ukraine. The conceptual data model. - [online] / H. Sereda // Information technology and learning tools - $\quad 2010 . \quad$ - $\quad № 2 \quad$ (16) — $\quad$ Available from http://journal.iitta.gov.ua/index.php/itlt/article/view/232/218\#.U7MKGbFnvvw (in Ukrainian).

22. Spivakovskyi O. University ICT infrastructure construction: problems and solutions [online] / O. Spivakovskyi, M. Vinnyk, Y. Tarasich // Information technologies and learning tools. — 2014. — № 1 39). $\quad$ - $\quad$ C. $\quad 99-116 . \quad-\quad$ Available from : http://journal.iitta.gov.ua/index.php/itlt/article/view/996\#.Uzz8sfl_t1Z (in Ukrainian).

23. Spirin O. Planning of the system of e-librarys of scientific and educational establishments of APS of Ukraine [online] / O. M. Spirin, V. M. Saukh, V. A. Reznichenko, O. V. Novyckiy // Information Technologies and Learning Tools. - 2009. — № 6(14). — Available from : http://journal.iitta.gov.ua/index.php/itlt/article/view/213/199 (in Ukrainian)

24. Spirin O. Conceptual basis of the national academy of pedagogical scie.nces of ukraine digital libraries network construction [online] / O. M. Spirin, S. M. Ivanova, O. V. Novyckiy // Information Technologies and Learning Tools. - 2012. - № 5(32). — Available from : http://journal.iitta.gov.ua/index.php/itlt/article/view/743/547 (in Ukrainian).

25. Creating educational web-space for learning [online] / W. Valuyska, M. Goncharenko, A. Pawlowski, A. Novatskyy. — Available from : http://uiite.kpi.ua/fileadmin/_wfqbe/1245139683_web.

26. Philosophical Encyclopedic Dictionary / [ed. by L. Il'ichev]. — Moskow: Soviet dictionary, 1983. — 840 p. (in Russian)

27. Authentication $\quad$ Plugins $\quad-\quad$ Available fonline]. https://wiki.duraspace.org/display/DSDOC3x/Authentication+Plugins.

28. Keller W. Enterprise Application Integration / Wolfgang Keller. - Leseprobe, 2002. - 840 p. (in English).

29. OAI-PMH integrated search webpart [online]. - Available from : https://openarchiveswp.codeplex.com/ (in English).

30. REST API [online]. - Available from : https://wiki.duraspace.org/display/DSPACE/REST+API (In English).

31. The Open Archives Initiative Protocol for Metadata Harvesting [online]. - Available from : http://www.openarchives.org/OAI/openarchivesprotocol.html\#DefinitionsConcepts (in English). 